\title{
Harga Diri dan Kemalasan Sosial pada Mahasiswa LSO (Lembaga Semi Otonom)
}

\section{Self Esteem and Social Loafing on LSO (Lembaga Semi Otonom) Students}

\author{
Gita Ayuningtyas Putri, Iswinarti*, Istiqomah \\ Fakultas Psikologi Universitas Muhammadiyah Malang \\ *Email corresponding author: iswinarti.psi@gmail.com
}

\begin{abstract}
KATA KUNCI Kemalasan Sosial, Harga Diri, Mahasiswa.
KEYWORDS Social Loafing, Self Esteem, Students.
\end{abstract}

ABSTRAK

Kemalasan sosial (social loafing) terjadi pada individu yang mengurangi usahanya dalam menyelesaikan beban tanggung jawab dalam kelompok dibandingkan saat individu tersebut bekerja tidak dalam kelompok. Salah satu faktor yang mempengaruhi kemalasan sosial antara lain adalah faktor harga diri. Individu yang memiliki harga diri yang tinggi, terdorong untuk berprestasi dan bersungguh-sungguh dalam pengerjaan tugas atau proyek yang tergolong sulit. Tujuan penelitian ini adalah untuk mengetahui hubungan antara harga diri dengan kemalasan sosial. Subjek penelitian merupakan mahasiswa anggota LSO (Lembaga Semi Otonom) Universitas X sejumlah 90 orang. Pengambilan data menggunakan skala kemalasan sosial yang disusun oleh peneliti sendiri dan skala harga diri dari Hidayati. Hasil penelitian menunjukkan bahwa ada hubungan negatif antara harga diri dengan kemalasan sosial pada mahasiswa $(r=-$ $0,416 ; p<0,05)$. Harga diri berkontribusi sebesar 17,3\% terhadap kemalasan sosial. Individu dengan harga diri yang tinggi memiliki kecenderungan bersikap positif dan kesadaran untuk berpartisipasi aktif dalam kelompok. Untuk mengurangi kemalasan sosial maka perlu adanya stimulasi yang diberikan agar setiap anggota kelompok merasa berharga atau memiliki harga diri yang positif.

ABSTRACT Social loafing occurs in individuals who reduce their effort to complete the burden of responsibility in the group that compared to when they work not in the group. One of the factors that influence social loafing is self-esteem. Individuals who have high self-esteem, are driven to excel and are serious in carrying out a difficult task or project. The purpose of this study was to determine the relationship between self-esteem and social laziness. The research subjects were 90 students of LSO (Lembaga Semi Otonom) University X members. The data were collected using the social laziness scale compiled by the researcher himself and the selfesteem scale from Hidayati. The results showed that there was a negative relationship between self-esteem and social laziness in students $(r=-$ 
0.416; $p$ <0.05). Self-esteem contributed $17.3 \%$ to social loafing. Individuals with high self-esteem have a positive tendency and awareness to participate actively in groups. To reduce social loafing, it is necessary to provide stimulation so that each group member feels valuable or has positive self-esteem.

\section{PENDAHULUAN}

Mahasiswa sebagai anggota masyarakat, perlu bersosialisasi dengan lingkungan sekitarnya. Interaksi mahasiswa bisa terjadi dalam sebuah kelompok yang mengharuskan mereka untuk saling berinteraksi. Ada berbagai kelompok mahasiswa seperti kelompok belajar, kegiatan kemahasiswaan, dan berbagai kelompok pengembangan mahasiswa. Salah satu kegiatan kelompok mahasiswa yaitu organisasi mahasiswa yang masingmasing mahasiswa memiliki tugas dan tanggung jawab masing-masing dalam kepengurusan organisasi tersebut. Ada permasalahan yang cukup sering muncul dalam berorganisasi ataupun dalma kegiatan kelompok, yaitu keaktifan mahasiswa untuk berkontribusi dalam pengerjaan dan kegiatan tersebut. Fenomena seperti ini dapat dikategorikan sebagai kemalasan sosial (social loafing). Menurut Latané, Williams, dan Harkins (1979), kemalasan sosial mengacu pada situasi dimana orang cenderung untuk mengurangi upaya individu ketika mereka bekerja secara kolektif daripada ketika mereka bekerja secara individual.

Interaksi individu di dalam organisasi memberikan harapan setiap anggotanya untuk menyelesaikan tanggung jawab dan tugas masing-masing. Harapan tersebut terkadang tidak berjalan lancer karena muncul anggapan bahwa anggota organisasi yang lain kurang terlibat dalam aktivitas organisasi dan cenderung bermalas-malasan. Hal tersebut dapat menurunkan motivasi dan usaha anggota lain untuk terlibat dalam usaha kelompok. Ketidakseimbangan kerja sama dalam kelompok memunculkan beberapa anggota bekerja keras sedangkan yang lainnya hanya melakukan sedikit usaha bahkan tidak berkontribusi sama sekali (Luthan, 2007). Kemalasan sosial yang muncul pada setiap kelompok sosial atau organisasi menjadi sebuah fenomena yang menarik untuk dibahas. Kemalasan sosial memberikan dampak yang kurang baik pada organisasi atau kelompok bahkan berdampak buruk pada kelompok lainnya.

Kemalasan sosial muncul karena individu memiliki kepercayaan bahwa tugas atau pekerjaan di dalam kelompok telah atau akan dikerjakan oleh anggota yang lain. Harapan individu akan performance anggota kelompok lain muncul karena adanya hubungan sosial antar anggota dalam kelompok jenis additive task. Jenis kelompok tersebut merupakan jenis kelompok yang memiliki pola usaha yang terorganisir untuk menghasilkan suatu produk. Usaha yang terorganisir tersebut memerlukan kerja sama setiap anggota (Latane, William, dan Harkins, 1979). Pada praktiknya tidak semua anggota kelompok bekerja bersamasama dalam upaya terorganisir tersebut. Beberapa orang bekerja keras, sedangkan beberapa lainnya kurang terlibat bahkan enggan mengeluarkan usaha sedikitpun. Fenomena tersebut merupakan kemalasan sosial yang terjadi di dalam kelompok.

Menurut Latane, Williams, dan Harkins (1979), kemalasan sosial diindikasikan dengan adanya penurunan kinerja individu secara berkelompok dibandingkan saat bekerja sendiri. Kemalasan sosial juga diartikan sebagai motivasi dan usaha yang berkurang ketika bekerja secara kolektif dibandingkan ketika hanya menjadi rekan independen. Para ahli menddefinisikan kemalasan sosial sebagai kecenderungan individu dalam mengurangi 
upaya saat bekerja kelompok. Dengan demikian kemalasan sosial didefinisikan sebagai kecendurungan individu yang berada dalam situasi kelompok yang menggunakan sedikit upaya dan kemampuan yang dimilikinya ketika diminta untuk berpartisipasi untuk mencapai tujuan bersama (Karau \& Williams, 1993).

Selain itu, ditemukan permasalahan terkait kemalasan sosial pada anggota organisasi mahasiswa dalam penelitian Wildanto (2016) seperti mahasiswa yang sengaja menghindar dari tanggung jawabnya. Hasil survey pada 50 anggota organisasi mahasiswa menunjukkan beberapa hal yang menyebabkan kemalasan sosial seperti beban tugas tidak sesuai target, hasil pekerjaan tidak maksimal, konflik antar anggota kelompok, anggota kelompok yang mengundurkan diri, dan kesalahan komunikasi.

Menurut Latane, Williams, dan Harkins (1981) kemalasan sosial memiliki dua dimensi yaitu dilution effect dan immediacy gap. Dimensi dilution effect mengacu pada individu dengan motivasi yang menurun yang disebabkan adanya perasaan bahwa pekerjaan dan kontribusinya tidak berarti. Penyebab lainnya yaitu tidak ada adanya penghargaan yang diberikan atas pekerjaan yang telah dilakukan. Dimensi immediacy gap diartikan sebagai kondisi individu yang merasa terasingkan dari kelompoknya. Hal tersebut mengindikasikan bahwa individu yang semakin menjauh, menarik diri, ataupun merasa memiliki jarak dengan anggota kelompok lain memiliki potensi yang tinggi untuk berkurangnya beban tugas yang diberikan kepadanya.

Selain itu, penelitian yang dilakukan oleh Webb (1997) menunjukkan bahwa rasa takut individu dalam menunjukkan ketidakpahaman akan tugas yang diberikan dan kurangnya asertivitas menjadi penyebab kemalasan sosial pada mahasiswa. Adapun mahasiswa yang berpendapat yaitu upayanya tidak berguna karena anggota kelompok yang lainnya akan beranggapan upaya atau kontribusi yang diberikan tidak berguna bagi kelompok. Dengan demikian, dengan adanya situasi tersebut dapat menyebabkan mahasiswa terkadang memilih untuk bersikap diam, tidak peduli, malu, serta ragu-ragu (Riyanto \& Th, 2008).

Adapun faktor-faktor penyebab individu melakukan kemalasan sosial, yaitu tidak adanya evaluasi (Harkins \& Szymanski, 1989), gender (Kugihara, 1999), menumpang kesuksesan (Kidwell \& Benner, 1993), ketidakjelasan tugas yang diberikan (George, 1992), faktor pada budaya (Early, 1989), tugas yang mudah (Harkins \& Petty, 1982), kepercayaan diri seseorang (Mukti, 2013), kelekatan pada kelompok (Karau \& Williams, 1997). Selain itu, menurut Sarwono (2005), terdapat tiga faktor lainnya yang juga mempengaruhi kemalasan sosial yaitu faktor kepribadian, jenis pemerhati, harga diri. Menurut Sarwono (2005), seseorang yang memiliki harga diri tinggi akan terdorong untuk menghasilkan prestasi sebaik-baiknya saat dengan orang lain, terutama dalam mengerjakan tugas-tugas yang termasuk sulit. Maka individu tersebut ingin memperlihatkan kemampuannya yang tinggi kepada orang lain.

Kemalasan sosial memberikan dampak pada individu mapun organisasi. Dampak kemalasan sosial pada individu yaitu individu memiliki pengetahuan yang lebih sedikit tentang tugas dalam kelompok dibandingkan anggota kelompok lain, memiliki keterbatasan untuk dapat mengembangkan diri dan melatih keterampilan di dalam kelompok, dan produktivitas menjadi terhambat (Latane, Williams, \& Harkins, 1979). Dampak kemalasan sosial bagi kelompok yaitu adanya situasi dan kondisi yang kurang nyaman di dalam kelompok yang diakibatkan dari rasa iri dan sedih setiap anggota karena beban tugas yang tidak seimbang tetapi dituntut untuk tetap mencapai target. Hubungan sosial setiap anggota kelompok juga terdampak serta 
mempengaruhi motivasi anggota kelompok lainnya (Teng \& Luo, 2015).

\section{Menurut Coopersmith}

bahwa harga diri merupakan hasil evaluasi seseorang terhadap dirinya sendiri yang ditunjukkam dalam sikap terhadap diri sendiri. Evaluasi diri mengacu pada sikap penerimaan dan penolakan akan dirinya sendiri. Harga diri seseorang juga mengacu pada rasa percaya bahwa dirinya mampu, berarti, berharga, dan berhasil sesuai standard ataupun nilai yang ditetapkan untuk dirinya. Harga diri merupakan gagasan atau pandangan mengenai diri secara global yang mengacu pada keseluruhan evaluasi diri sebagai manusia atau bagaimana individu merasakan tentang dirinya dalam makna yang komprehensif (Verkuyten, 2003). Menurut Baron dan Byrne (2012), harga diri adalah evaluasi diri yang dibentuk sendiri oleh individu dan menunjukkan sikap terhadap dirinya sendiri baik secara positif maupun negatif.

Adapun empat aspek harga diri menurut Copersmith (1967) yaitu power, significance, virtue, dan competence. Power yang berarti kekuasaan merupakan kemampuan individu untuk mengontrol dan melakukan pengaturan pada tingkah laku diri sendiri maupun orang lain. Significance yang berarti keberartian merupakan aspek penghargaan dan minat dari orang lain yang diberikan kepada seorang individu baik berupa kepedulian, perhatian, dan afeksi. Virtue yang berarti kebajikan merupakan wujud individu dalam ketaatan. Hal tersebut dapat dilihat dalam sikap individu dalam mengikuti moral dan prinsip keagmaan seperti menjauhi perilaku yang dilarang dan melakukan perilaku yang diperbolehkan oleh moral, etika, dan agama. Competence yang berarti kemampuan diwujudkan dalam upaya dan pencapaian atau keberhasilan individu dalam menyelesaikan berbagai macam beban tugas yang diberikan kepadanya, serta dapat memenuhi suatu target capaian dan tuntutan prestasi.

Harga diri individu diwujudkan dalam evaluasi dan konsep diri sendiri baik secara positif maupun negatif. Individu menjadikan harga diri positif sebagai syarat utama untuk mencapai pemenuhan hidup. Motivasi individu untuk memperoleh harga diri yang positif terwujud dalam perilakunya. Hal tersebut dikarenakan keputusan seseorang merupakan cerminan harga diri orang tersebut baik secara implisit maupun eksplisit. Harga diri seseorang menggambarkan kemampuannya dalam menghadapi setiap tantangan, terutama dalam menyelesaikan berbagai beban tugas dan pekerjaan dalam kelompok baik secara individual maupun bersamasama dengan anggota kelompok lainnya.

Harga diri yang semakin tinggi berpengaruh pada sikap positif yang semakin meningkat pada individu. Salah satu faktor yang mempengaruhi meningkatnya harga diri individu dalam kelompok yaitu adanya rasa menghargai pemimpin kepada anggota kelompok. Kurangnya motivasi karena rendahnya harga diri dapat menjadi penyebab kemalasan sosial dari seorang individu (Shepperd, 1993).

Menurut Hogg dan Vaughan (2002), harga diri yang positif pada seseorang menimbulkan perasaan nyaman akan diri orang tersebut dan membuat orang tersebut dapat mengatasi kecemasan, penolakan sosial ataupun rasa kesepian. Menurut Sarwono (2005) bahwa seseorang memiliki harga diri yang tinggi memiliki dorongan yang kuat untuk berprestasi dengan sungguh-sungguh terutama ketika dihadapkan dengan tugas-tugas yang sulit.

Dalam penelitian Kusuma (2015) ditunjukkan bahwa mahasiswa yang memeiliki harga diri yang tinggi cenderung mengerjakan tugasnya dalam kelompok, bekerja sama dengan anggota lain, dan berkontribusi dalam menyelesaikan berbagai tanggung jawabnya ataupun membantu pekerjaan yang menjadi tanggung jawab anggota lain yang merasa kesulitan. Mahasiswa yang memiliki harga diri yang tinggi juga mampu mengoptimalkan potensinya dengan 
memberikan ide ataupun gagasan untuk pengembangan kelompok.

Penelitian terdahulu yang dilakukan oleh Kusuma (2015) terkait harga diri dan kemalasan sosial menggunakan subjek mahasiswa Universitas X pada tahun 2015 yang terdiri dari sembilan kelas. Adapun jumlah populasi dalam penelitian tersebut terdiri dari 433 mahasiswa. Penelitian ini menggunakan subjek yaitu mahasiswa yang menjadi anggota Lembaga Semi Otonom (LSO) termasuk sebagai kelompok sekunder. Menurut Cooly (2007) terdapat ciri-ciri kelompok sekunder ialah terbentuk atas dasar kemauan anggotanya, interaksi atau hubungan sosial yang formal. Fungsi dari LSO ini tidak hanya untuk perlombaan saja, melainkan terdapat struktur keorganisasian berupa anggota yang mempunyai komitmen dan tanggung jawab terhadap program kerja yang telah di rencanakan, dan adanya tuntutan dalam pencapaian untuk membuat dan menghasilkan proyek-proyek besar secara ilmiah yang akan segera diperlombakan. Dengan demikian, alasan peneliti memilih subjek dengan kriteria ini yaitu karena di dalam LSO tersebut terdapat tugas dan proyek-proyek yang menantang, menarik, dan membuat individu akan merasa lebih berupaya dalam berkontribusi untuk bekerja kelompok.

Berdasarkan uraian-uraian tersebut, maka peneliti mmerumuskan masalah penelitian ini yaitu apakah ada hubungan antara harga diri dengan kemalasan sosial pada anggota LSO Universitas X. Tujuan penelitian ini adalah untuk mengungkapkan hubungan antara harga diri dengan kemalasan sosial pada anggota LSO Universitas X. Hipotesis pada penelitian ini bahwa ada hubungan negatif antara harga diri dengan kemalasan sosial, yaitu semakin tinggi harga diri, maka semakin rendah perilaku kemalasan sosial pada mahasiswa LSO Universitas X. Sebaliknya jika harga diri rendah maka kemalasan sosial tinggi pada mahasiswa LSO Universitas X. Penelitian ini bermanfaat untuk mengetahui bagaimana gambaran harga diri dan kemalasan sosial pada anggota LSO Universitas X. Hasil penelitian ini dapat memberikan manfaat pada suatu kelompok secara umum (anggota kelompok LSO Universitas $\mathrm{X}$ pada khususnya) yaitu memberikan informasi kepada anggota suatu kelompok terkait kamalasan sosial sehingga dengan adanya penelitian ini individu dapat meminialisir dampak negatifnya.

\section{METODE PENELITIAN Partisipan}

Subjek dalam penelitian ini adalah 90 mahasiswa yang menjadi anggota LSO Universitas $\mathrm{X}$ yang terdiri atas LSO Workshop Robotika, LSO Surya Team, dan LSO Mekatronic. Deskripsi subjek penelitian dapat dilihat pada tabel 1 . Metode pengambilan sampel yang digunakan dalam penelitian ini adalah metode sampel jenuh. Sampling jenuh adalah teknik penentuan sampel bila semua anggota populasi digunakan sebagai sampel. 
Tabel 1

Deskripsi Subjek Penelitian

\begin{tabular}{lcc}
\hline \multicolumn{1}{c}{ Kategori } & Frekuensi & Jumlah \\
\hline Usia & 33 anggota $(36,6 \%)$ & 90 \\
$18-20$ tahun & 57 anggota $(63,4 \%)$ & \\
$21-24$ tahun & 74 anggota $(82,2 \%)$ & 90 \\
Jenis Kelamin & 16 anggota $(17,8 \%)$ & \\
$\quad$ Laki-laki & & 90 \\
Perempuan & 28 anggota $(31,1 \%)$ & \\
LSO & 35 anggota $(38,9 \%)$ & \\
Mekatronic & 27 anggota $(30,0 \%)$ & \\
Surya Team &
\end{tabular}

\section{Instrumen}

$\begin{array}{crr}\begin{array}{c}\text { Kemalasan } \\ \text { kecenderungan }\end{array} & \text { sosial } & \text { adalah } \\ \text { seseorang } & \text { dalam }\end{array}$ mengurangi upaya atau usaha yang dikeluarkan saat mengerjakan tugas atau proyek secara kelompok dibandingkan ketika bekerja secara individual. Kemalasan sosial diukur menggunakan skala kemalasan sosial yang disusun oleh peneliti sendiri berdasarkan dimensi-dimensi kemalasan sosial yang telah dikemukakan oleh Latane, Williams, dan Harkins (1981) yaitu dimensi dilution effect dan immediacy gap. Skala kemalasan sosial tersusun atas 21 aitem, menggunakan skala Likert dengan empat pilihan respon dari SS (sangat Setuju) hingga STS (Sangat Tidak Setuju).

Harga diri merupakan keseluruhan nilai diri yang digunakan untuk menilai sifat dan kemampuan. Harga diri dapat mempengaruhi kognitif seseorang dalam menghadapi kegagalan. Individu dengan harga yang tinggi akan mempertahankan nilai dirinya dengan mengartikan bahwa orang lain juga belum berhasil dan dengan membesar-besarkan keunggulannya terhadap orang lain. Skala ini disusun oleh Hidayati (2016) kemudian dimodifikasi oleh peneliti berdasarkan empat aspek yang digunakan dalam menyusun skala ini adalah aspek dari Coopersmith (1967) yaitu power (kekuatan), virtue (kebajikan), significance (keberartian), dan competence (kemampuan). Skala harga diri terdiri dari 15 aitem. Adapun indeks validitas dan reabilitas dari instrumen harga diri dan kemalasan sosial dapat dilihat pada tabel 2 .

Tabel 2

Hasil Pengukuran Validity Index dan Cronbach's Alpha pada Alat Ukur

\begin{tabular}{lcccc}
\hline \multicolumn{1}{c}{ Skala } & Item & Valid item & $\begin{array}{c}\text { Validity } \\
\text { index }\end{array}$ & Cronbach's Alpha \\
\hline Kemalasan sosial & 21 & 17 & $0,222-$ & 0,840 \\
Harga diri & 15 & 15 & 0,728 & $0,235-$ \\
& & & 0,552 & 0,807 \\
\hline
\end{tabular}

Pada tahap pelaksanaan penelitian, peneliti melakukan pengambilan data dengan menyebarkan dua skala, yaitu skala kemalasan sosial dan skala harga diri.
Kedua skala yang telah valid dan reliabel ini diberikan kepada mahasiswa anggota LSO bidang keilmuan di Fakultas Teknik, yaitu Universitas Muhammadiyah Malang yang 
terdiri dari dari LSO Workshop Robotika, LSO Surya Team dan LSO Mekatronic dengan jumlah 90 subjek.

\section{Teknik Analisis Data}

Pada tahap analisis, tahap terakhir ini skala yang telah disebarkan kepada jumlah total 90 subjek akan diinput dan dianalisis menggunakan program statistik SPSS 22. Analisis yang dilakukan menggunakan uji korelasi product moment untuk menguji hubungan antara kedua variabel independen dan dependen (Sugiyono, 2017).

\section{ANALISIS DAN HASIL}

Dalam penelitian ini, adapun hasil analisis pada $T$ - score dapat dilihat pada tabel 3 .
Hasil T-score yang menunjukkan data kategori variabel harga diri dan kemalasan sosial, yaitu anggota yang memiliki harga diri rendah dan tinggi, serta anggota yang memiliki kemalasan sosial rendah dan tinggi pula. Dengan demikian, dapat dilihat bahwa dari jumlah keseluruhan subjek yaitu 90 mahasiswa anggota LSO bidang teknologi, terdapat 39 anggota dengan persentase $43,3 \%$ memiliki harga diri yang tinggi dan 51 anggota dengan persentase $56,7 \%$ memiliki harga diri yang rendah. Selain itu, pada kemalasan sosial, terdapat 50 anggota dengan persentase $96,7 \%$ memiliki kemalasan sosial yang tinggi dan 40 anggota dengan persentase $44,4 \%$ memiliki kemalasan sosial yang rendah.

Tabel 1

Perhitungan T-Score Variabel Harga Diri dan Kemalasan Sosial

\begin{tabular}{cccc}
\hline Variabel & Kategori & Frekuensi & Presentase \\
\hline Harga Diri & Tinggi & 39 & $43,3 \%$ \\
& Rendah & 51 & $56,7 \%$ \\
Kemalasan Sosial & Tinggi & 50 & $96,7 \%$ \\
& Rendah & 40 & $44,4 \%$ \\
\hline
\end{tabular}

*) Catatan: Tinggi: skor $>50$; Rendah: skor $\leq 50$

\section{Uji Normalitas}

Sebelum peneliti menguji variabel harga diri dan kemalasan sosial, peneliti melakukan uji kenormalan data dengan skewness kurtosis. Berdasarkan uji skewness dan kurtosis, pada variabel kemalasan sosial menunjukkan nilai skewness dan kurtosis sebesar 0,001 dan 0,061 , sedangkan pada variabel harga diri menunjukkan nilai skewness dan kurtosis sebesar 0,429 dan 0,779. Berdasarkan hasil perhitungan tersebut, dapat disimpulkan bahwa data dikatakan normal dikarenakan angka skewness dan kurtosis berada pada \pm 2 , hal ini menunjukkan bahwa dengan data tersebut dapat dilakukan uji regresi linier.

\section{Uji Hipotesis}

Dari analisis data penelitian menggunakan teknik analisis product moment pearson diperoleh hasil koefisien korelasi (r) sebesar -0,416 dengan signifikan $p<0,05$. Hasil ini menunjukkan ada hubungan negatif yang sangat signifikan antara variabel harga diri dengan kemalasasan sosial, yang artinya semakin tinggi harga diri maka semakin rendah kemalasan sosial pada mahasiswa anggota LSO bidang teknologi. Begitu pula sebaliknya, jika semakin rendah harga diri maka semakin tinggi kemalasan sosial pada mahasiswa anggota LSO bidang teknologi. Hasil penelitian ini juga menemukan bahwa terdapat koefisien determinasi $\left(\boldsymbol{r}^{2}\right)$ sebesar 0,173 atau $(17,3 \%)$. Sehingga hal ini menunjukkan sumbangan harga diri terhadap kemalasan sosial sebesar 17,3\% dan adapun sisanya sebesar $82,7 \%$ dapat dipengaruhi oleh faktor lain. 
Tabel 2

Hasil uji hipotesis $(N=90)$

\begin{tabular}{lllll}
\hline$r$ & $r^{2}$ & $P$ & Ket & Kesimpulan \\
\hline$-0,416$ & 0,173 & 0,000 & $\mathrm{P}<0,05$ & signifikan \\
\hline
\end{tabular}

\section{DISKUSI}

Tujuan dari penelitian ini adalah untuk mengetahui hubungan antara harga diri dengan kemalasan sosial pada mahasiswa anggota LSO bidang teknologi. Berdasarkan penelitian yang telah dilakukan dapat diperoleh hasil yaitu menunjukkan terdapat hubungan negatif yang signifikan dari harga diri dan kemalasan sosial. Hal ini menunjukkan bahwa semakin tinggi harga diri maka semakin rendah kemalasan sosial pada mahasiswa anggota LSO bidang teknologi, begitu pula sebaliknya semakin rendah harga diri maka semakin tinggi kemalasan sosial pada mahasiswa anggota LSO bidang teknologi.

Adanya kemalasan sosial tentunya dapat merugikan kelompok serta anggota yang lainnya. Kelompok yang dirugikan karena adanya kemalasan sosial pada suatu anggota kelompok maka mengakibatkan produktivitas anggota kelompok lain tidak bekerja secara efektif dan maksimal (Audi, 2014). Selain itu, kerugian yang dialami oleh anggota yang memiliki perilaku kemalasan sosial dapat mengakibatkan terhambatnya untuk mengembangkan pengetahuan dan kemampuan yang dimilikinya dalam mengerjakan tugas kelompok. Penelitian Simon (1991) menyatakan bahwa tidak adanya penghargaan pribadi untuk karyawan yang telah mengeluarkan kinerja yang efektif dapat mengurangi kinerjanya yang telah menempatkan utilitas yang lebih besar pada kemalasan sosial. Hal tersebut merupakan wujud dari dimensi kemalasan sosial yaitu dilution effect.

Harga diri menjadi salah satu faktor yang mempengaruhi kemalasan sosial (Sarwono, 2005). Seseorang yang memiliki harga diri rendah memiliki kecenderungan untuk melakukan perilaku kemalasan sosial karena sesuai dengan definisi harga diri yang merupakan penilaian seorang individu terhadap dirinya, baik penilaian positif maupun penilaian negatif. Harga diri yang tinggi akan membuat individu memiliki penilaian positif terhadap dirinya serta berkaitan dengan kemampuan dan sikapnya. Penilaian pada anggota LSO bidang teknologi ini baik negatif maupun positif akan mempengaruhi bagaimana para anggota memberikan kontribusinya untuk kelompok, bersikap dalam menjalin komunikasi untuk kelompok, dan adanya interaksi atau hubungan sosial dalam kelompok.

Berdasarkan penelitian yang dilakukan oleh Nelfice, Elita, dan Dewi (2014), ciri-ciri seseorang yang memiliki harga diri tinggi adalah dapat melakukan interaksi sosial dan hubungan sosial yang baik dengan orang yang berada disekitarnya. Dengan demikian, hal tersebut sesuai dengan penelitian ini bahwa anggota LSO bidang teknologi yang memiliki harga diri tinggi mampu melakukan hubungan sosial yang baik dengan anggota yang lainnya khususnya dalam membuat sebuah proyek dalam kelompok.

Coopersmith

mengemukakan ciri-ciri individu berdasarkan tingkat harga dirinya. Salah satu ciri individu yang memiliki harga diri tinggi yaitu menyukai tugas baru yang menantang serta berhasil atau berprestasi di bidang akademik, aktif dan dapat mengekpresikan dirinya dengan baik. Dengan demikian, dapat dikatakan bahwa motivasi berprestasi juga mempengaruhi kemalasan sosial pada mahasiswa. Hal ini didukung oleh penelitian yang dilakukan 
oleh Dewi (2017) yaitu terdapat hubungan yang sangat signifikan antara motivasi berprestasi dengan kemalasan sosial, yaitu semakin tinggi motivasi berprestasi pada subjek maka semakin rendah perilaku kemalasan sosial. Dengan demikian, individu memiliki motivasi berprestasi yang tinggi akan bertanggung jawab dengan perbuatannya. Hal ini sesuai dengan teori yang dikemukakan Myers (2012) yaitu kemalasan sosial terjadi karena menurunnya motivasi seseorang untuk terlibat dalam kerja kelompok.

Penelitian ini didukung juga oleh teori Maslow (dalam Alwisol, 2014) yang menyatakan bahwa individu dengan harga diri tinggi dapat memperoleh penghargaan diri dari orang lain berdasarkan kemampuan yang dimilikinya bukan berdasarkan kemampuan orang lain. Dengan demikian, individu tidak akan mengakui kemampuan anggota yang lainnya dalam anggota kelompoknya sebagai kemampuannya, yang artinya adalah individu tidak akan bergantung dengan kelompok terutama pada anggota kelompok yang dirasa memiliki kemampuan lebih. Akan tetapi, apabila individu dengan harga diri yang rendah maka individu menjadi tidak peduli dan tidak mau ikut berkontribusi dalam pengerjaan tugas ataupun proyek. Hal tersebut sesuai dengan penelitian ini bahwa terdapat jumlah anggota yang cukup besar yang memiliki harga diri yang rendah.

Penelitian sebelumnya yang dilakukan oleh Hidayati (2016) mengatakan bahwa ada hubungan negatif yang signifikan antara harga diri dengan kemalasan sosial pada mahasiswa. Seseorang yang memiliki penilaian positif atau memiliki harga diri yang tinggi cenderung untuk lebih berambisi, memiliki kemungkinan untuk menjadi seseorang yang lebih kreatif dalam pekerjaannya dan dapat membina hubungan interpersonal yang baik. Hal tersebut dapat dikatakan bahwa sangat memungkinkan bagi seseorang dengan harga diri yang tinggi untuk mengembangkan potensi yang dimilikinya. Potensi yang dimiliki oleh seseorang dapat mendorongnya untuk berpikir lebih positif tentang dirinya.

Adapun penelitian yang dilakukan oleh Wildanto (2016) terkait kemalasan sosial pada anggota organisasi. Hasil penelitian tersebut menunjukan bahwa adanya bentuk-bentuk kemalasan sosial yang dilakukan oleh anggota organisasi yaitu anggota organisasi tidak menjalankan tugas yang diberikan, tidak menjalankan program kerja yang telah dibuat dalam organisasi, tidak mau mencoba hal baru atau tugas baru selain tugas yang telah diperintahkan, tidak pernah memberikan upaya atau kontribusi berupa ide atau gagasan didalam organisasi.

Pada studi yang dilakukan oleh Smith, Tyler, Huo, Ortiz, dan Lind (1998) bahwa ditemukan pada ekspresi rasa hormat seorang pemimpin kelompok terhadap anggotanya, maka cenderung dapat meningkatkan harga diri pada anggota kelompok. Oleh karena itu, semakin seseorang disukai dan dihormati dengan teman-teman sekelompok, maka semakin besar tanggung jawab yang akan dilakukan terhadap teman sekelompoknya (Wentzel, 1994).

Pada anggota LSO bidang teknologi yang memiliki harga diri tinggi cenderung dapat menunjukkan kemalasan sosial yang lebih rendah, begiu pula sebaliknya pada anggota LSO yang memiliki harga diri rendah cenderung dapat menunjukkan kemalasan sosial saat bekerjasama. Hal tersebut dapat dilihat dari hasil uji hipotesis pada penelitian ini yaitu terdapat hubungan negatif yang sigifikan bahwa semakin tinggi harga diri, semakin rendah kemalasan sosial pada anggota LSO bidang teknologi begitu pula sebaliknya semakin rendah harga diri maka semakin tinggi kemalasan sosial. Dengan demikian, pada anggota LSO bidang teknologi akan memiliki penilaian positif pada anggota yang lainnya karena penilaian positif maupun negatif akan mempengaruhi kontribusi anggota dalam kerja kelompok. Selain itu, dengan memiliki sikap positif terhadap anggota kelompok, hal ini juga 
dapat membuat anggota kelompok menjadi percaya diri untuk berupaya dan menunjukkan kontribusi yang maksimal dalam kelompok guna meningkatkan status dan menjadikan individu layak bagi LSO bidang teknologi seperti LSO Workshop Robotika, Surya Team, dan Mekatronic. Selain itu, dengan memiliki harga diri yang tinggi ini para anggota mampu melakukan hubungan sosial yang baik dengan anggota yang lainnya, khususnya dalam membuat sebuah proyek dalam kelompok.

\section{SIMPULAN}

Berdasarkan penelitian yang telah dilakukan maka dapat ditarik kesimpulan bahwa harga diri berhubungan secara negatif dan signifikan terhadap kemalasan sosial. Hal ini telah dibuktikan dengan hasil uji statistika yang dapat dikatakan bahwa semakin tinggi harga diri maka semakin rendah kemalasan sosial pada mahasiswa anggota LSO bidang teknologi dan juga sebaliknya, semakin rendah harga diri maka semakin tinggi kemalasan sosial pada anggota LSO bidang teknologi. Memiliki harga diri yang tinggi dapat memunculkan sikap positif dan penilaian positif pada individu tersebut guna memiliki perasaan bahwa individu siap untuk berpartisipasi dalam kehidupan orang lain, sehingga dalam LSO Workshop Robotika, Surya Team, dan Mekatronic diharapkan para anggota memiliki sikap positif dan penilaian positif karena hal tersebut dapat mempengaruhi perilaku kemalasan sosial.

\section{SARAN}

Saran pada penelitian ini, kepada para anggota LSO bidang teknologi ialah sebaiknya tingkatkan kembali harga diri. Adapun cara meningkatkan harga diri dengan memperhatikkan kembali aspekaspeknya yaitu kekuatan, kebajikan, keberartian, dan kemampuan. Hal ini dilakukan bertujuan agar anggota LSO bidang teknologi ini dapat meningkatkan partisipasi serta keaktifan di dalam LSO sehingga anggota lebih dihargai dan dibutuhkan oleh kelompok serta dapat mengurangi perilaku kemalasan sosial saat bekerja secara kelompok dalam mengerjakan sebuah proyek.

Dalam penelitian ini masih terdapat kekurangan, sehingga peneliti memberikan beberapa rekomendasi yaitu diharapkan agar peneliti selanjutnya dapat menggunakan jumlah subjek yang lebih besar dan menggunakan teknik sampel yang lainnya. Selain itu, peneliti selanjutnya sebaiknya dapat mengembangkan judul penelitian dengan variabel yang lainnya agar menghasilkan temuan yang menarik.

\section{DAFTAR PUSTAKA}

Alwisol. (2014). Psikologi kepribadian. UMM Press.

\section{Arikunto, S. (2012). Prosedur penelitian suatu pendekatan praktik. Rineka Cipta.}

Audi, N., L. (2014). Persahabatan dan toleransi pemalasan sosial pada mahasiswa Psikologi Universitas Sumatera Utara. Psikologia, 9(2), 5256.

Baron, R.A \& Byrne,D. (2012). Psikologi sosial jilid dua $\left(10^{\text {th }}\right.$ ed.). Erlangga.

Coopersmith, S. (1967). The antecedents of self esteem. W. H. Freeman.

Dewi, S. S. (2017). Hubungan motivasi berprestasi dengan social loafing pada mahasiswa psikologi Universitas Medan Area. Consilium, 4(4), 106-121.

Early, P. C. (1989). Social loafing and collectivism: A comparison of the United States and the People's Republic of China. Administrative Science Quarterly, 34, 565-581.

George, J. M. (1992). Extrinsic and intrinsic origins of perceived social loafing in organizorganizations. Academy of Management Journal, 35, 191-202.

Harkins, S.G., \& Szymanski, K. (1989). Social loafing and Group Evaluation. Journal of Personality and Social Psychology, 56, 934-941. 
Harkins, S. G., \& Petty, R. E. (1982). Effects of task difficulty and task uniqueness on social loafing. Journal of Personality and Social Psychology, 43(6), 1214-1229.

Hogg, M. A., \& Vaughan, G. M. (2002). Social psychology ( $3^{\text {rd }}$ ed.). Tottenham Court Road.

Hidayati, N. (2016). Hubungan antara harga diri dan kepercayaan diri dengan social loafing pada mahasiswa [Thesis Undergraduate]. Universitas Katolik Soegijapranata.

Karau, S. J., \& Williams, K. D. (1993). Social loafing : A meta-analytic review and theoretical integration. Journal of Personality and Social Psychology, 65, 681-706.

Kugihara, N. (1999). Gender and social loafing in Japan. The Journal of Social Psychology, 139, 516-526.

Kusuma, P. J. (2015). Hubungan antara harga diri dengan kemalasan sosial pada mahasiswa [Thesis Undergraduate, Universitas Muhammadiyah Surakarta]. http://eprints.ums.ac.id/36113/1/NAS

KAH\%20PUBLIKASI.pdf.

Latané, B., Williams, K. D., \& Harkins, S. (1979). Many hands make light the work: work: The causes and consequences of social loafing. Journal of Person Personality and Social Psychology, 37(6), 822-832.

Latane, B., Williams, K. D., \& Harkins, S. (1981). Identifiability as a deterrant to social loafing: Two cheering experiments. Journal of Personality and Social Psychology, 40(2), 303-311.

Luthans, Fred. (2007). Perilaku organisasi. Andi.

Mukti, P. (2013). Hubungan antara kepercayaan diri dan motivasi berprestasi dengan social loafing pada mahasiswa [Thesis Undergraduate, Universitas Muhamadiyah Surakarta].
http://eprints.ums.ac.id/27807/15/Nask ah_Publikasi.pdf.

Myers, D. G. (2012). Exploring social psychology (6 ${ }^{\text {th }}$ ed.). New York: McGrow-Hill Companies, Inc.

Nelfice., Elita, V., \& Dewi, Y, I. (2014). Hubungan dukungan keluarga dengan harga diri remaja di lembaga permasyarakatan. Jurnal Online Mahasiswa Program Studi Ilmu Keperawatan. 1(3), 1-10.

Riyanto, T., \& Th., M. (2008). Kelompok kerja yang efektif. Kanisius.

Sarwono, S. W. (2005). Psikologi sosial: Psikologi kelompok dan psikologi terapan. Balai Pustaka.

Sugiyono. (2017). Metode penelitian pendidikan (pendekatan kuantitatif, kualitatif, $R \& D)$ ). Alfabeta.

Shepperd, J. A. (1993). Productivity loss in performance groups: A motivation analysis. Psychological Bulletin, 113, 67-81.

Simon, H. A. (1991). Organizations and markets. Journal of Economic Perspectives, 5, 25-44.

Smith, H., Tyler, T., Huo, Y., Ortiz, D., \& Lind, E. (1998). The self relevant implications of the group-value model: Group membership, self-worth, and treatment quality. Journal of Experimental Social Psychology, 34, 470-493.

Teng, C., \& Luo, Y. (2015). Effects of perceived social loafing, social interdependence, and group affective tone on students' group learning performance. Asia-Pacific Education Researcher, 24(1), 259-269.

Verkuyten, M. (2003). Positive and negative self-esteem among ethnic minority early adolescents: Social and cultural sources and threats. Youth and Adolescence, 32(4), 267-277. 
Webb, N. (1997). Assesing students in small collaborative groups. Theory Into Practice, 36(4), 205-213.

Wentzel, K. (1994). Relations of social goal pursuit to social acceptance, classroom behavior, and perceived social support. Journal of Educational Psychology, 86, 173-182.
Wildanto, E. (2016). Social loafing pada anggota organisasi mahasiswa fakultas psikologi UMS [Thesis Undergraduate, Universitas Muhammadiyah Surakarta]. http://eprints.ums.ac.id/47018/22/03.\% 20Halaman\%20Depan.pdf. 